\title{
Celebrity Endorsement and Customer Loyalty in the Telecommunications Industry in Port Harcourt
}

\author{
Bright ZorBari-Nwitambu ${ }^{1}$, Sylva Ezema Kalu ${ }^{2}$ \\ ${ }^{1}$ Library Department, Ken Saro-Wiwa Polytechnic, Bori \\ ${ }^{2}$ Marketing Department, University of Port Harcourt, Port Harcourt-Nigeria
}

*Corresponding Author: Bright ZorBari-Nwitambu, Library Department, Ken Saro-Wiwa Polytechnic, Bori-Ogoni, Rivers State, Nigeria, Email: makorobright@gmail.com

\begin{abstract}
This paper focused on examining the relationship between celebrity endorsement and customer loyalty in the telecommunications industry in Port Harcourt. To achieve this, we sought to know the opinion of 50 top managers/ contact staff of the 5 major telecommunications giants in Port Harcourt namely; MTN Nigeria, Glo, Airtel, 9mobile (formerly Etisalat) and Starcomms on how a favourite celebrity can influence consumers' choice of patronage of their brands using 50 copies of structured questionnaire. Correlation analysis with Spearman's rank correlation coefficient (rho) and regression analysis were carried out with the aid of the SPSS 20.0 software, to ascertain the association between studied variables and the extent of their relationship respectively. Also, a reliability test with chronbach alpha of 0.7 benchmark was conducted and the result of the study was 0.9 indicating a high reliability of the research instrument. Drawing on the theory of marketing communication, we concluded that while all predictors have a positive relationship with the criterion variable, celebrity trustworthiness and credibility were discovered to have significant influence on customer loyalty in the telecommunications industry in Port Harcourt. Based on the conclusion, we recommend that Telecommunications companies should hire the services of only those celebrity endorsers that are trustworthy and credible enough to represent the company in good light.
\end{abstract}

Keywords: Marketing communication, Ccelebrity endorser, Telecommunications sector.

\section{INTRODUCTION}

The telecommunications industry has in recent times witnessed a tremendous upturn in patronage due to the use of various communication strategies for awareness creation on the existence of products. However, enough literature on the significance of the use of celebrity endorsement on customer loyalty has not been extensively reviewed. The telecoms sector is saturated and filled with intense competition with several companies and brand names striving to outperform one another and winning the customers all to themselves. This has resulted in the use of various marketing strategies to win the hearts of the ever dynamic, educated and enlightened customers of today's market. Prominent among the strategies employed by major Telecommunication giants is the celebrity endorsement strategy (Waldt, Loggerenberg and Wehmeyer, 2009). The world has become a global village where information is being disseminated in a split of second (Asogwa, Ohaleme and Ugwuanyi, 2013). Also, with various online platforms and social media (Facebook, WhatsApp, YouTube, LinkedIn, Twitter, etc.), favourite celebrities can be accessed and followed online. Savvy marketing communication experts are taking advantage of fame and followership of these celebrities to draw attention, gain attraction and customer loyalty of the various brands these celebrities represent. With the advent of Global System for Mobile communication (GSM), many companies have emerged searching daily for strategies that can be best employed to win a greater share of the market. One of such strategies includes proper communication of the products existence to members of the public.

Savvy marketing communication experts have realized that another avenue of making the public aware of their brands and sticking to them is the use of celebrity endorsement. This is especially so in the tertiary institutions where youths and teenagers are the core dominant of the segment.

Celebrity endorsement is a marketing campaign in which companies use popular and famous personalities to promote and create awareness on the product/service. These celebrities use their fame 
and popularity to influence members of the public to patronize the product and impact on consumers buying behaviours. To ensure success, companies should choose celebrities carefully; making sure a particular choice of endorsement actually represents the overall features of the brand/company (Poghosyan, 2015).

Celebrities influence consumers' personal buying decision in a number of ways. A consumer may want to buy the very product used by or advertised by a particular celebrity simply because he/she is attracted to that celebrity and wishes to be like him (the celebrity). Teenagers for instance are a large group of target audience that are easily influenced by celebrity endorsement as they see celebrities as their idol that they try to imitate and as a result would buy those products advertised by their favourite celebrities (Ateke, Onwujiariri, Nnennanya, 2015).

Most Telecomm users in Port Harcourt and its environs have one or more favourite celebrity (ies) they see as their idols and will patronize brands that are advertised by these celebrities. The reason is that they have developed so much liking and passion for them that they wish to be like these celebrities and so the starting point to them is to use what there celebrities use, buy what they buy, and do those things their favourite celebrities asked them to do (in adverts).

Generally speaking, customers like to identify with brands that will give them value for their money. Marketing communication experts and mobile communication giants like; MTN Nigeria, Airtel, Etisalat, Globacom, Starcomms, etc. use celebrity endorsement to reduce the uncertainties on the minds of potential users of their products, as customers view the celebrities' advice concerning a particular brand as a resolve for being loyal to such brand.

Studies have revealed that the use of eye-catching personalities will facilitate the acceptability of a product (Ahmed, Seedani, Ahuja, and Paryani, 2015) and further enhance the memorability of such product to customers (Ateke, Onwujiariri \& Nnnenanya, 2015).

Previous studies have looked at the success of celebrity endorsement strategy over the years as an effective marketing communication tool (Jain, 2011; Bergkvist, and Zhou, 2016; Apeoye, 2013). However, much has not been said on how this strategy can be used to achieve customer loyalty in the telecommunications industry. It is in this light that this paper tends to explore the relationship between celebrity endorsement and customer loyalty, and the extent to which a favourite celebrity endorser can influence a customer to remain loyal to a particular brand.

\subsection{Background to the Study}

The theoretical underpinning of this study is drawn on marketing communication theory. Marketing communication is the strategy a firm uses to convey messages regarding its products/ services directly or indirectly to target audience in order to generate sales/ patronage. One prominent means of creating awareness in the market place nowadays is the use of famous personalities who use their popularity and social status to project a firm's image and convey messages concerning its product offerings to members of the public. This practice or strategy is referred to as celebrity endorsement.

\subsection{Aim and Objectives of the Study}

The study aimed at investigating the relationship between celebrity endorsement and customer loyalty in the Telecommunications sector and also to determine the extent of this relationship.

Giving the above aim, the study's specific objectives include investigating the extent to which;

1. Perceived expertise influences customer loyalty in the Telecommunications sector in Port Harcourt.

2. Trustworthiness influences customer loyalty in the Telecommunications sector in Port Harcourt

3. Credibility influences customer loyalty in the Telecommunications industry in Port Harcourt

4. Belief influences customer loyalty in the Telecommunications industry in Port Harcourt

\section{LITERATURE REVIEW}

The practice of engaging famous personalities to use their fame and popularity to project the image and products of a company has received much acceptance. Marketers believe that celebrity endorsers are the right people to speak to the public about their products (Jain, 2011). Celebrities enjoy huge 
popularity and followership (Apeoye, 2013) and are easily able to grab the audience attention (Zipporah and Mberia, 2014).

For a celebrity endorser to be well accepted by the members of public he must portray certain unique characteristics that is capable of projecting the image of the firm high if employed (Chaudhary and Asthana, 2015).

Ranging from consumer goods to services, Business-to-Business (B-2-B), and not-for-profit organizations, corporations have over the years achieved great success using this marketing communication strategy (Bergkvist and Zhou, 2016).In lieu of this, scholars like Hassan and Jamil (2014); Silvera and beneditkts (2003), Ohanian (1990), cited in Ibok (2013) have proposed some of the features of celebrity endorsement. They are: perceived expertise, trust worthiness, credibility, amongst others. In this paper we propose belief as an additional determining factor that influences choice of celebrity endorsement.

\subsection{Perceived Expertise}

Celebrity expertise is the degree to which a celebrity communicates to the public in line with the objectives of the advert/ message and overall aim of the company. It has to do with the competence of the celebrity endorser as regards the message being communicated to the public. In the words of Malik and Qureshi (2016), perceived expertise is concerned with the experience, skill and grounded knowledge of the celebrity to promote the product.

Bergkvist and Zhou(2016) pointed out three things that should be put into consideration in selecting a celebrity to include celebrity-target audience match, celebrity-product/brand match and overall image of the celebrity. There should be some degree of conformity/ match between a celebrity and the product he/ she represents (Pamar and Patel, 2015).

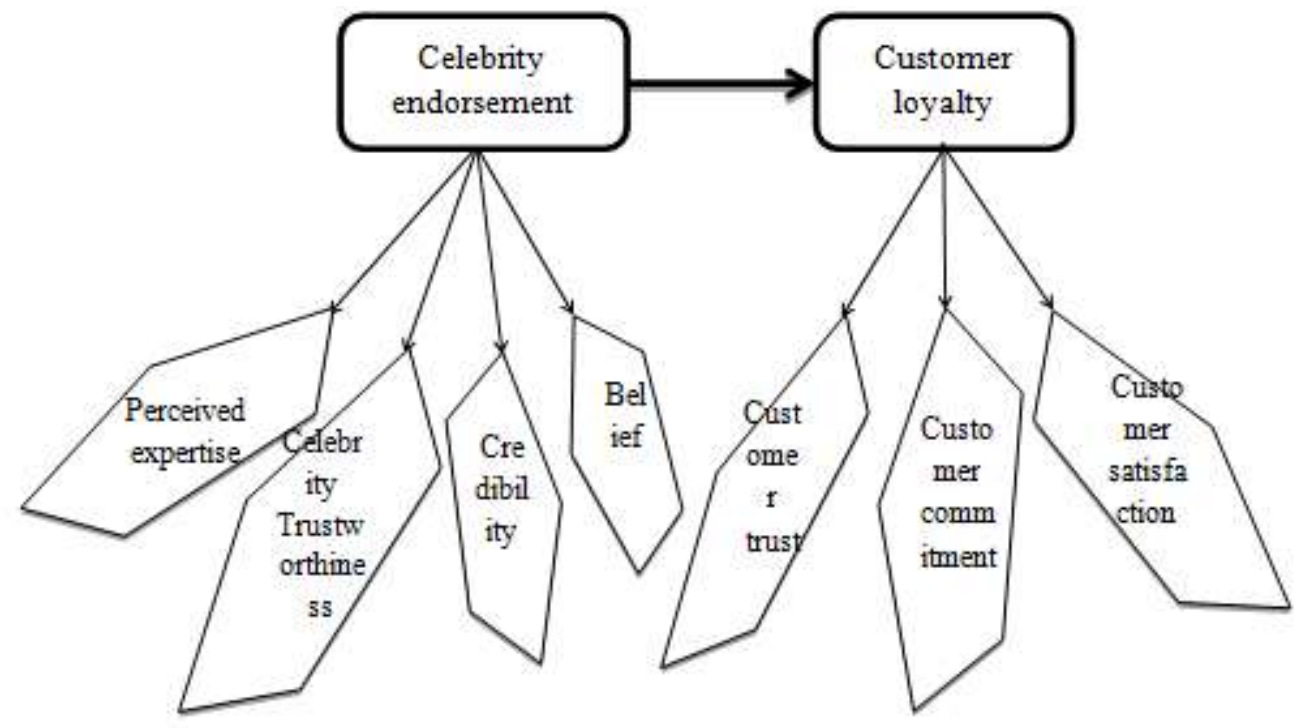

Figure1. Study's Conceptual Framework

The level of expertise and competence displayed by a celebrity in getting the message across to the public will also earn him/ her likability. Consumers will tend to have a positive disposition towards a celebrity who is good at what he or she does, thereby commanding more attraction and followership. The celebrity represents what the company and its brand stand for, and so he must portray an image that will not paint the organization in bad light.

\subsection{Celebrity Trust Worthiness}

The character/profile of the celebrity can make or mar an advertising campaign. Celebrities therefore need to take specific actions in ensuring that they live a scandal-free life, worthy of trust and emulation. Trustworthiness is level of confidence and believability that consumers pose in a celebrity endorser to represent the product in a most valid way. Some attributes of trust include favourable disposition and wide acceptance of the celebrity and the brand he/ she represents (Pamar and Patel, 2015). 
Celebrity's trustworthiness has been proven to result in greater attitude change than perceived expertise, and has strong effect on celebrity endorsement effectiveness. Fans and followers of celebrities will consciously or unconsciously patronise a celebrity endorsed product based on personal held trust in the celebrity. Celebrity endorsement is pivotal to the success of Telecomm companies (Ibok, 2013) and the celebrity trust is often transferred on the overall image of the company.

\subsection{Credibility}

Credibility is the integrity, honesty and dependability of the celebrity as regards the subject matter. Endorser's credibility is popularly used in marketing to influence customer buying behaviour. This suggests that the effectiveness of the communication will largely depend on the expertise and trustworthiness of the celebrity as viewed by customers (Malik and Qureshi, 2016). Trustworthiness and expertise are both components of credibility (Willemsen, Neijens and Bronner, 2011) and is believed to be perceived and not an absolute phenomenon (Mishra, Dhar and Raotiwala, 2001). Previous research indicates that Source credibility poses more effect on consumer judgment and choice (Willemsen, Neijens and Bronner, 2011). Credibility determines whether or not an advertising message will impact positively on the receiver; it influences the outcome of the communicated message (Serban, 2010).

\subsection{Belief}

Cultural or religious belief of a target audience can influence a firm's choice of celebrity. People of a particular culture may be emotionally attached to a celebrity that is one of their own, who speaks their language and dress like them. In the same manner, religious affiliation can be so influential on target market. Example in the Northern part of the country, adverts targeted at Northerners will yield a wider appeal if the company engages the services of a Muslim celebrity for the advert. The dress code of a Muslim female star wearing a hijab will appeal to Muslim faithful that share similar faith and belief with the celebrity.

A celebrity's acquaintance with the cultural and religious norms of the people will also free him from scandals capable of painting him/ her in bad light in the eyes of his/ her supporters. Consumers may be sceptical about the sincerity of a firm's activity $((\mathrm{Hsieh} \& \mathrm{Li}, 2008)$ but assurance from a reputable and famous celebrity would calm their fears as regards the genuineness of the product.

\subsection{Customer Loyalty}

Over the past decades, customer loyalty has gained higher attention in marketing literature (Haghkhah, Hamid, Ebrahimpour, Roghanian and Gheysari, 2013).Many authors agree that the cost of retaining a customer is far less than acquiring one. Customer loyalty leads to cost minimization in business and enhances business performance. In the words of Soderlund (2006), customer loyalty refers to the consistent mutual relations between a customer and a vendor or service provider over time regarding a given brand. Loyalty entails that there must be a level of consistency in the way a customer relate to a firm's product. Loyalty has been viewed as a proven source of competitive advantage; also, loyal customers are bound to be less price-sensitive. Soderlund(2006) has opined that re-patronage intentions and word-of-mouth intentions are a subset of loyalty intentions. Improving and maintaining customer loyalty entails that a firm tailors its services to the ever dynamic needs and lifestyles of already acquired customers, by so doing customers are retained for life (Lee, Barker and Kandampully, 2003).

Customer loyalty can be defined based on attitudinal and behavioural measures (Rauyreun, Miller and Barrett, 2007). Attitudinal loyalty is the customer's intention to maintain a relationship with a service provider. Behavioural loyalty on the other hand is the number of time a customer repeats his purchase with the same company relative to competing brands. It is pertinent to note that not all intentions lead to action or actual purchase of the product. Repeat purchase is guaranteed by the degree of satisfaction a customer derives from using a product and the products' perceived value.

In view of the above, Oliver (1999) propounded the four stages of loyalty which include; cognitive affective - conative - action. Cognitive loyalty recognises that a brand exists. The desire to purchase must first begin with the consumer's conscious or subconscious acceptance that a need exists and that a particular product is available to solve such need. Affective loyalty refers to a customer's positive attitude towards a particular brand. In this stage of loyalty, the consumer demonstrates strong liking 
towards a brand out of numerous brands in the same category. Conative loyalty is a strong commitment on the path of the consumer to buy the product. At this stage, the consumer has both the will and the power (finance) to buy. Action is the last stage where the consumer having considered all factors decides to make actual purchase. The duty of a marketer is to monitor the consumer throughout the entire process to ensure that all first three stages metamorphoses into the action stage and further do a proper follow-up to ensure the last stage is memorable to warrant a repeat purchase leading to a re-cycling of the above process.

It is however noteworthy that a memorable experience during the first encounter in the cycle will minimize the learning process and the wavering intention of the customer regarding whether to or not to make purchase as will be encountered in the first purchase process. A loyal customer will spend less time in searching for and making attentive purchase evaluation. Loyalty comprises of attitudinal and behavioural loyalty. Attitudinal loyalty has been viewed as the desire to maintain a relationship with a particular organization (i.e. strength of preference). Behavioural loyalty is seen as the customer's tendency of repeating purchase and increasing repurchase rates/ sequence (Jones and Taylor, 2007). This aspect of loyalty was later considered incomplete as it did not differentiate true customer loyalty from spurious customer loyalty that may arise from lack of alternative (Chang and Chen, 2009).

Some customers buy a particular brand because of the satisfaction derived from that brand (true loyalty) others may choose to patronise a particular brand available at the time to solve their immediate need, or due to cost involved in switching brands they have decided to stick with the brand not necessarily because they are passionate about the brand (Spurious Loyalty).True loyalty entails a customer passing through the cognition, affection, conation and action phase of loyalty (Toufaily, Ricard and Perrien 2012).Cognitive loyalty emphasises brand performance and willingness to pay more for a particular product, affective loyalty is concerned with brand preference, conative loyalty focuses on repeat purchase, and action loyalty lays emphasis on converting intentions into action.

However some authors have argued that attitudinal and behavioural loyalty alone does not address the concept of loyalty in its entirety (Worthing, Russell-Bennett and Hartel, 2009). To bridge the gap resulting from this, we have the composite loyalty. Composite loyalty is the combination of behavioural and attitudinal loyalty to have a better predictive power. In this case, loyalty is viewed as a customer's repurchase (behavioural intention) and also high preference and impression for a particular product or service provider. Commitment leads to behavioural aspect of loyalty while word of mouth leads to attitudinal loyalty. Worthing, Russell-Bennett and Hartel, (2009) are arguing that loyalty should be viewed from a tri-dimensional perspective which includes emotional, cognitive and behavioural loyalty. The duty of a marketer is to ensure that intentions are converted into actions, as intentions in themselves are imperfect representation of the customers' behaviour that may not necessarily result in actual purchase (Bontis, Booker and Serenko, 2007).

Dick and Basu (1994) pointed out that societal norms and a number of situational factors contribute significantly to customer loyalty. Customer loyalty is the core of strategic marketing planning because the objective of strategic marketing is to attract and keep profitable customers so that they don't switch to competitors' brands. Studies often report that on the average, it costs a company more to attract new customers than retain existing ones (Lee-Kelley, Gilbert and Mannicom, 2003). Customer loyalty thereby reduces costs on the part of the organization as it does not require much cost to implement a retention strategy compared to customer acquisition strategies. Studies have also shown that loyalty programs will lead to repurchase behaviour and repurchase intentions, i.e. the implementation of loyalty programs and other marketing policies that will encourage and lure customers to try out the product can lead to brand loyalty overtime (Bolton, Kannan and Bramlett, 2000). A true customer is one who is brand loyal and can stay with the company for profitably longer period of time, being an enduring asset and not a looming liability (Shugan, 2005).

Some drivers of customer loyalty may include amongst others; customer perceived value, customer satisfaction and switching cost.

In light of the above, Aydin, Ozer and Arasil (2005) have identified the major determinants of customer loyalty as switching cost, customer satisfaction and trust. Switching cost is the total amount a customer is likely to spend for changing from one product/service to another. Simply put, a customer is bound to be loyal to brand that provides value for money, and will patronise product that 
gives optimum satisfaction. In addition, a customer may decide to stick with a particular service provider having considered the time and cost involved to switch to competitors' brands. Service providers must strive to ensure that a product/service actually delivers the value it promised to deliver. This in turn will uphold the trust the consumer has in the brand/company and strengthens customer loyalty. A loyal customer will develop a high degree of trust and commitment towards the company and its brand and also demonstrate strong satisfaction in the products and service delivery process. Giving the foregoing, this paper will use customer trust, customer commitment and customer satisfaction as indices to measure customer loyalty. They are further discussed hereunder:

\subsection{Customer Trust}

Many authors see trust as a central construct in developing and sustaining mutual service relationships among customers and for the attainment of customer loyalty. This entails that the customers' safety must be guaranteed at all times, and that customers need to be assured and re-assured of confidentiality in their dealings with a particular organization. Most scholars have argued that organizations that wish to gain customer loyalty must first of all gain customer trust. Customer trust is often developed based on experience with a particular brand.

Trust is an experience attribute that is based on customers direct (trial, consumption, etc.) or indirect (advertising, third - party conviction, etc.) contact with the brand (Delgado-Ballester and MunueraAlemaAn, 2001).Prominent among all those means of trust is the consumption experience because it gives the consumer a first-hand feeling and self-assurance making his judgement and assessment of trust to be more certain.

Customer trust is a major driver of customer loyalty in telecom industry. In order to gain the trust of customers, companies must ensure that they endorse or employ the services of only those celebrities that are trustworthy and free of negative impressions capable of attracting negative comments and portraying bad image to the firm/organization. Customers trust in a particular celebrity can be transformed on the company brand, thereby enhancing customer loyalty.

\subsection{Customer Commitment}

This is referred to as a customer's intention to remain dedicated to the cause of maintaining a relationship with service provider. Commitment can be regarded as a relationship benefit and is a function of the satisfaction derived from previous encounter with a business partner (Haghkhah, Hamid, Ebrahimpour, Roghanian and Gheysari, 2013). A committed customer is one who does not switch between competing brands and is seen as a firm's most valuable asset. Customer commitment has remained one of most common yardsticks for measuring customer lifetime value (CLV) in marketing. Customer commitment plays a crucial role in the evolving focus of marketing to include customer involvement and customer participation whereby firms don't just manufacture products that suit the needs of customers but allow the customers to be involved in the manufacturing process of products that fulfil their own needs (Huang and Huddleston, 2009).

\subsection{Customer Satisfaction}

The key to customer loyalty is satisfaction. Many authors posit that customer satisfaction is a major determinant of loyalty. It is evidenced in consumer marketing literature that satisfaction plays a key role in consumer repurchases intentions, behavioural intentions, customer retention and customer loyalty. Satisfied customers stick to the firm's brand and often times turn to advocates of the brand. Customer satisfaction is an evaluation that is based on direct experience with the product and thus influences consumer's personal consumption experience (Suh and Yi, 2006; Lervik-Olsen and Johnson, 2003). Past experience is one determining factor that informs a customer to act either favourably or otherwise towards a product.

Customer satisfaction has been proven to be a major antecedent of customers' interpersonal trust and loyalty (Ribbink, Riel, Liljander and Streukens, 2004). That is, a customer is first satisfied with a firm's brand before being loyal to such brand, and, the more satisfied a customer is with the product/service, the more loyal he becomes to the brand and this further strengthens the customer's trust in not just the brand but builds overall loyalty to the company.

In addition, satisfaction in the form of using the product coupled with switching cost can make a customer to remain loyal to a particular brand.

Giving the above, we state the following alternate hypotheses: 
$\mathrm{HA}_{1}$ : There is a significant relationship between perceived expertise and customer trust in the Telecommunication industry in Port Harcourt.

$\mathrm{HA}_{2}$ : There is a significant relationship between celebrity trustworthiness and customer trust in the Telecommunications industry in Port Harcourt.

$\mathrm{HA}_{3}$ : There is a significant relationship between credibility and customer trust in the Telecommunications industry in Port Harcourt.

$\mathrm{HA}_{4}$ : There is a significant relationship between belief and customer trust in the Telecommunications sector in Port Harcourt.

$\mathrm{HA}_{5}$ : There is a significant association between perceived expertise and customer commitment in the Telecommunications sector in Port Harcourt.

$\mathrm{HA}_{6}$ : There is a significant association between celebrity trustworthiness and customer commitment in the Telecommunications sector in Port Harcourt.

$\mathrm{HA}_{7}$ : There is a significant association between credibility and customer commitment in the Telecommunications sector in Port Harcourt.

$\mathrm{HA}_{8}$ : There is a significant association between belief and customer commitment in the Telecommunications sector in Port Harcourt.

$\mathrm{HA}_{9}$ : There is a significant relationship between perceived expertise and customer satisfaction in the Telecommunications industry in Port Harcourt.

$\mathrm{HA}_{10}$ : There is a significant positive relationship between celebrity trustworthiness and customer satisfaction in the Telecommunications industry in Port Harcourt.

$\mathrm{HA}_{11}$ : There is a significant relationship between credibility and customer satisfaction in the Telecommunications industry in Port Harcourt.

$\mathrm{HA}_{12}$ : There is a significant relationship between belief and customer satisfaction in the Telecommunications sector in Port Harcourt.

\section{Methodology}

The study is a correlational study that involves field survey as 50 copies of questionnaire were distributed among top management and other contact staff of the studied Telecommunications companies in Port Harcourt. Data generated were subjected to correlation and regression analyses to ascertain the relationship between studied variables and the extent of such relationship, using Spearman's rank correlation coefficient (rho) with the aid of the SPSS 20.0 software. More so, a reliability test with 0.7 chronbach alpha benchmark was conducted to ascertain the consistency of the research instrument, and the result shows a high reliability of 0.9 .

\section{ANALYSIS, SUMMary OF FINDINGS AND DISCUSSION}

The results of analyses on the data obtained through structured copies of questionnaire are discussed as follows;

\subsection{Bivariate Analyses}

Table4.1. Correlation matrix showing the relationship between independent variable and dependent variable

\begin{tabular}{|c|c|c|c|c|c|c|c|c|}
\hline \multicolumn{9}{|c|}{ Correlations } \\
\hline & & 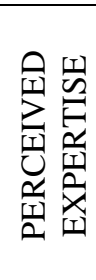 & 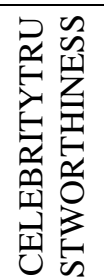 & 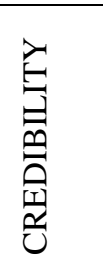 & 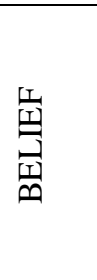 & 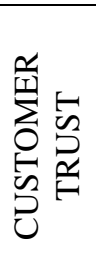 & 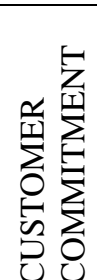 & 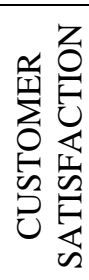 \\
\hline \multirow{2}{*}{$\begin{array}{l}\text { PERCEIVED } \\
\text { EXPERTISE }\end{array}$} & $\begin{array}{l}\text { Pearson } \\
\text { Correlation }\end{array}$ & 1 & $.982^{* * *}$ & $.938^{* *}$ & $.972^{* * *}$ & $.955^{* *}$ & $.973^{* * *}$ & $.958^{* * *}$ \\
\hline & Sig. (2-tailed) & & .000 & .000 & .000 & .000 & .000 & .000 \\
\hline
\end{tabular}




\begin{tabular}{|c|c|c|c|c|c|c|c|c|}
\hline & $\mathrm{N}$ & 50 & 50 & 50 & 50 & 50 & 50 & 50 \\
\hline \multirow{3}{*}{$\begin{array}{l}\text { CELEBRITYTR } \\
\text { USTWORTHINE } \\
\text { SS }\end{array}$} & $\begin{array}{l}\text { Pearson } \\
\text { Correlation }\end{array}$ & $.982^{* *}$ & 1 & $.948^{* *}$ & $.967^{* *}$ & $.968^{* *}$ & $.981^{* *}$ & $.947^{* 3}$ \\
\hline & Sig. (2-tailed) & .000 & & .000 & .000 & .000 & .000 & .000 \\
\hline & $\mathrm{N}$ & 50 & 50 & 50 & 50 & 50 & 50 & 50 \\
\hline \multirow[t]{3}{*}{ CREDIBILITY } & $\begin{array}{l}\text { Pearson } \\
\text { Correlation }\end{array}$ & $.938^{* *}$ & $.948^{* *}$ & 1 & $.934^{* *}$ & $.967^{* *}$ & $.969^{* *}$ & $.929^{* * 3}$ \\
\hline & Sig. (2-tailed) & .000 & .000 & & .000 & .000 & .000 & .000 \\
\hline & $\mathrm{N}$ & 50 & 50 & 50 & 50 & 50 & 50 & 50 \\
\hline \multirow[t]{3}{*}{ BELIEF } & $\begin{array}{l}\text { Pearson } \\
\text { Correlation }\end{array}$ & $.972^{* *}$ & $.967^{* *}$ & $.934^{* *}$ & 1 & $.940^{* *}$ & $.948^{* *}$ & $.941^{* * 3}$ \\
\hline & Sig. (2-tailed) & .000 & .000 & .000 & & .000 & .000 & .000 \\
\hline & $\mathrm{N}$ & 50 & 50 & 50 & 50 & 50 & 50 & 50 \\
\hline \multirow[t]{3}{*}{$\begin{array}{l}\text { CUSTOMER } \\
\text { TRUST }\end{array}$} & $\begin{array}{l}\text { Pearson } \\
\text { Correlation }\end{array}$ & $.955^{* *}$ & $.968^{* *}$ & $.967^{* *}$ & $.940^{* * *}$ & 1 & $.983^{* *}$ & $.969^{* * 3}$ \\
\hline & Sig. (2-tailed) & .000 & .000 & .000 & .000 & & .000 & .000 \\
\hline & $\mathrm{N}$ & 50 & 50 & 50 & 50 & 50 & 50 & 50 \\
\hline \multirow[t]{3}{*}{$\begin{array}{l}\text { CUSTOMER } \\
\text { COMMITMENT }\end{array}$} & $\begin{array}{l}\text { Pearson } \\
\text { Correlation }\end{array}$ & $.973^{* *}$ & $.981^{* *}$ & $.969^{* *}$ & $.948^{* *}$ & $.983^{* *}$ & 1 & $.958^{* *}$ \\
\hline & Sig. (2-tailed) & .000 & .000 & .000 & .000 & .000 & & .000 \\
\hline & $\mathrm{N}$ & 50 & 50 & 50 & 50 & 50 & 50 & 50 \\
\hline \multirow[t]{3}{*}{$\begin{array}{l}\text { CUSTOMER } \\
\text { SATISFACTION }\end{array}$} & $\begin{array}{l}\text { Pearson } \\
\text { Correlation }\end{array}$ & $.958^{* * *}$ & $.947^{* *}$ & $.929^{* * *}$ & $.941^{* * *}$ & $.969^{* * *}$ & $.958^{* *}$ & 1 \\
\hline & Sig. (2-tailed) & .000 & .000 & .000 & .000 & .000 & .000 & \\
\hline & $\mathrm{N}$ & 50 & 50 & 50 & 50 & 50 & 50 & 50 \\
\hline
\end{tabular}

**Correlation is significant at the 0.01 level (2-tailed).

The correlation table 4.1 above indicates that there is a strong correlation between the studied variables. This is evidenced in the variables' strong correlation coefficient with double asterisk. Also, the result of the correlation matrix reveals that all studied variables are highly correlated at $0.000<$ 0.05 significance/ probability value (PV).

In the above table, the relationship between Perceived expertise and customer trust was analysed and the result of the correlation coefficient $(r)=0.955^{* *}$ shows a high positive correlation.

Perceived expertise and customer commitment was also analysed to ascertain their relationship, and the correlation coefficient $(r)=0.973^{* *}$ reveals a positively strong association.

Also, the spearman correlation coefficient $(r)=0.958^{* *}$ indicates a strong positive correlation between perceived expertise and customer satisfaction.

Furthermore, the table reveals the relationship between celebrity trustworthiness and customer trust with correlation coefficient $(r)=0.986^{* *}$, this means a strong positive correlation.

We also analysed the relationship between celebrity trustworthiness and customer commitment, and the result shows a correlation coefficient ( $\mathrm{r}$ ) of $0.981^{* *}$; meaning a strong positive correlation exist between them.

The relationship between celebrity trustworthiness and customer satisfaction was further analysed, and the correlation coefficient $(r)=0.947 *$ implies that there is strong positive correlation between the two variables.

More so, the relationship between credibility and customer trust was analysed. The correlation coefficient $(r)=0.967 * *$ shows that there is a strong positive correlation between the variables.

We also ascertained the relationship between credibility and customer commitment, and the outcome of the correlation coefficient $(\mathrm{r})=0.969 * *$ indicated a strong positive correlation.

Furthermore, the relationship between credibility and customer satisfaction was examined, and the outcome as presented in the correlation table indicated that the correlation coefficient $(r)=0.929 * *$ which means there is high positive correlation between studied variables.

The table also reveals the relationship between belief and customer trust with correlation coefficient $(r)=0.940^{* *}$, this result shows strong positive association between the two variables. 
The relationship between belief customer commitment was further examined, and from the outcome of the correlation coefficient $(r)=0.948^{* *}$, we say that there is strong positive correlation between the studied variables.

Finally, we studied the relationship between belief and customer satisfaction. From the result, there is a high positive correlation among the variables as the correlation coefficient $(r)=0.9 .41 * *$.

\subsection{Multivariate Analysis}

Table4.2.1. Summary of Regression analysis on the predictors and customer trust

a. Dependent Variable: CUSTOMER_TRUST

b. All requested variables entered.

Model Summary

\begin{tabular}{|c|c|c|c|c|}
\hline Model & $\mathrm{R}$ & R Square & Adjusted R Square & Std. Error of the Estimate \\
\hline 1 & $.981^{\mathrm{a}}$ & .962 & .958 & .774 \\
\hline
\end{tabular}

a. Predictors: (Constant), BELIEF, CREDIBILITY, CELEBRITY_ TRUST WORTHINESS, PERCEIVED_ EXPERTISE

Table4.2.2. $A N O V A^{a}$

\begin{tabular}{|l|l|l|l|l|l|l|}
\hline \multicolumn{2}{|l|}{ Model } & Sum of Squares & df & Mean Square & F & Sig. \\
\hline \multirow{4}{*}{1} & Regression & 676.136 & 4 & 169.034 & 281.895 & $.000^{\mathrm{b}}$ \\
\cline { 2 - 7 } & Residual & 26.984 & 45 & .600 & & \\
\cline { 2 - 7 } & Total & 703.120 & 49 & & & \\
\hline
\end{tabular}

a. Dependent variables: CUSTOMER TRUST

b. Predictors: (Constant), BELIEF, CREDIBILITY, CELEBRITY_TRUSTWORTHINESS, PERCEIVED_ EXPERTISE

Table 4.2.3: Coefficients ${ }^{\mathrm{a}}$

\begin{tabular}{|c|c|c|c|c|c|c|}
\hline \multirow{2}{*}{\multicolumn{2}{|c|}{ Model }} & \multicolumn{2}{|c|}{$\begin{array}{l}\text { Unstandardized } \\
\text { Coefficients }\end{array}$} & $\begin{array}{c}\text { Standardized } \\
\text { Coefficients }\end{array}$ & \multirow[t]{2}{*}{$\mathrm{t}$} & \multirow[t]{2}{*}{ Sig. } \\
\hline & & $\mathrm{B}$ & Std. Error & Beta & & \\
\hline \multirow[t]{5}{*}{1} & (Constant) & -2.210 & 1.050 & & -2.104 & .041 \\
\hline & PERCEIVED_EXPERTISE & .072 & .125 & .102 & .581 & .564 \\
\hline & CELEBRITY TRUSTWORTHINESS & .530 & .187 & .498 & 2.838 & .007 \\
\hline & CREDIBILITY & .573 & .108 & .499 & 5.302 & .000 \\
\hline & BELIEF & -.079 & .097 & -.107 & -.819 & .417 \\
\hline
\end{tabular}

a. Dependent variables: CUSTOMER TRUST

Regression analysis was further carried out to ascertain the extent of relationship that exists among variables and to decide on whether to accept or reject the hypotheses earlier stated in the study.

Consequent upon this, all elements of the independent variable - perceived expertise, celebrity trustworthiness, credibility and belief were regressed against the first measure of the dependent variable - customer trust. The $\mathrm{r}^{2}=0.962$ in table 4.2 .1 indicates that $96.2 \%$ variation in customer trust is accounted for by the combination of perceived expertise, celebrity trustworthiness, credibility and belief. Also, there is significant relationship between the studied variables as the ANOVA table 4.2.2 shows a significant value $=0.000<(0.05)$ when all the elements of the independent variable have a combined effect on the dependent variable. However, the coefficient table 4.2.3 reveals that when each element of the independent variable is examined, celebrity trustworthiness and credibility show significant relationship on customer trust (Significance value $=0.007<(0.05)$ and $0.000<(0.05)$ respectively; perceived expertise and belief show insignificant relationship (Significance value $=0.564$ $>(0.05)$ and $0.417>(0.05)$ respectively.

Table4.2.4. Summary of Regression analysis on the predictors and customer commitment

a. Dependent Variable: CUSTOMER_COMMITMENT

b. All requested variables entered.

Model Summary

\begin{tabular}{|l|l|l|l|l|}
\hline Model & R & R Square & Adjusted R Square & Std. Error of the Estimate \\
\hline 1 & $.991^{\text {a }}$ & .981 & .980 & .687 \\
\hline
\end{tabular}

a. Predictors: (Constant), BELIEF, CREDIBILITY, TRUSTWORTHINESS, PERCEIVED_EXPERTISE 
Table4.2.5. $A N O V A^{a}$

\begin{tabular}{|l|l|l|l|l|l|l|}
\hline \multicolumn{2}{|l|}{ Model } & Sum of Squares & df & Mean Square & F & Sig. \\
\hline \multirow{4}{*}{1} & Regression & 1123.244 & 4 & 280.811 & 594.497 & $.000^{\mathrm{b}}$ \\
\cline { 2 - 8 } & Residual & 21.256 & 45 & .472 & & \\
\cline { 2 - 7 } & Total & 1144.500 & 49 & & & \\
\hline
\end{tabular}

a. Dependent Variable: CUSTOMER_COMMITMENT

b. Predictors: (Constant), BELIEF, CREDIBILITY, TRUSTWORTHINESS, PERCEIVED EXPERTISE

Table4.2.6. Coefficients ${ }^{a}$

\begin{tabular}{|c|c|c|c|c|c|c|}
\hline \multirow{2}{*}{\multicolumn{2}{|c|}{ Model }} & \multicolumn{2}{|c|}{$\begin{array}{l}\text { Unstandardized } \\
\text { Coefficients }\end{array}$} & \multirow{2}{*}{$\begin{array}{l}\text { Standardized } \\
\text { Coefficients } \\
\text { Beta } \\
\end{array}$} & \multirow[t]{2}{*}{$\mathrm{t}$} & \multirow[t]{2}{*}{ Sig. } \\
\hline & & $\mathrm{B}$ & Std. Error & & & \\
\hline \multirow[t]{5}{*}{1} & (Constant) & -4.944 & .932 & & -5.303 & .000 \\
\hline & PERCEIVED_EXPERTISE & .286 & .111 & .316 & 2.578 & .013 \\
\hline & CELEBRITY TRUSTWORTHINESS & .682 & .166 & .502 & 4.112 & .000 \\
\hline & CREDIBILITY & .587 & .096 & .401 & 6.115 & .000 \\
\hline & BELIEF & -.205 & .086 & -.218 & -2.391 & .021 \\
\hline
\end{tabular}

a. Dependent Variable: CUSTOMER_COMMITMENT

Furthermore, we did a multivariate analysis on all elements of the predictor variable - perceived expertise, celebrity trustworthiness, credibility and belief and the second measure of the criterion variable - customer commitment. The $\mathrm{r}^{2}=0.981$ in table 4.2 .4 revealed that $98.1 \%$ of what makes customers committed to a firm's brand is accounted for by the combined effect of perceived expertise, celebrity trustworthiness, credibility and belief of an endorsed celebrity. Also, the ANOVA table 4.2.5 shows that this combined effect shows a significant relationship among studied variables at $\mathrm{PV}=$ $0.000<0.05$ significance level. Consequently, table 4.2.6 revealed that all predictors have significant influence on the criterion variable as perceived expertise has significant value $(\mathrm{PV})=0.013>0.05$, celebrity trustworthiness $\mathrm{PV}=0.000<0.05$, credibility $\mathrm{PV}=0.000<0.05$, and belief $\mathrm{PV}=0.021>$ 0.05 .

Table4.2.7. Regression analysis on the predictors and customer satisfaction

a. Dependent Variable: CUSTOMER_SATISFACTION

b. All requested variables entered.

Model Summary

\begin{tabular}{|l|l|l|l|l|}
\hline Model & R & R Square & Adjusted R Square & Std. Error of the Estimate \\
\hline 1 & $.962^{\mathrm{a}}$ & .926 & .919 & 1.085 \\
\hline
\end{tabular}

a. Predictors: (Constant), BELIEF, CREDIBILITY, TRUSTWORTHINESS, PERCEIVED_EXPERTISE

Table4.2.8. $A N O V A^{a}$

\begin{tabular}{|l|l|l|l|l|l|l|}
\hline \multicolumn{2}{|l|}{ Model } & Sum of Squares & df & Mean Square & F & Sig. \\
\hline \multirow{3}{*}{1} & Regression & 659.873 & 4 & 164.968 & 140.206 & $.000^{\mathrm{b}}$ \\
\cline { 2 - 7 } & Residual & 52.947 & 45 & 1.177 & & \\
\cline { 2 - 7 } & Total & 712.820 & 49 & & & \\
\hline
\end{tabular}

a. Dependent Variable: CUSTOMER_SATISFACTION

b. Predictors: (Constant), BELIEF, CREDIBILITY, TRUSTWORTHINESS, PERCEIVED_EXPERTISE

Table4.2.9. Coefficients ${ }^{a}$

\begin{tabular}{|c|c|c|c|c|c|c|}
\hline \multicolumn{2}{|c|}{ Model } & \multicolumn{2}{|c|}{ Unstandardized Coefficients } & \multirow{2}{*}{$\begin{array}{c}\text { Standardized } \\
\text { Coefficients } \\
\text { Beta }\end{array}$} & \multirow[t]{2}{*}{$\mathrm{t}$} & \multirow[t]{2}{*}{ Sig. } \\
\hline & & B & Std. Error & & & \\
\hline \multirow[t]{5}{*}{1} & (Constant) & 9.916 & 1.471 & & 6.740 & .000 \\
\hline & PERCEIVED_EXPERTISE & .490 & .175 & .688 & 2.806 & .007 \\
\hline & TRUSTWORTHINESS & -.046 & .262 & -.043 & -.176 & .861 \\
\hline & CREDIBILITY & .287 & .151 & .249 & 1.898 & .064 \\
\hline & BELIEF & .060 & .135 & .081 & .444 & .659 \\
\hline
\end{tabular}

a. Dependent Variable: CUSTOMER_SATISFACTION

International Journal of Managerial Studies and Research (IJMSR) 
Finally, regression analysis was conducted on all elements of the independent variable - perceived expertise, celebrity trustworthiness, credibility and belief and the third measure of the dependent variable- customer satisfaction. The $\mathrm{r}^{2}=0.926$ in table 4.2 .7 indicates that $92.6 \%$ variation in customer satisfaction is brought about by the combined use of all elements of the independent variable. Also, the ANOVA table shows that the combined effects of all elements of the independent variable have significant relationship with the customer satisfaction. However, it is discovered in table 4.2.9 that only perceived expertise show a significant relationship with customer satisfaction with probability/ significant value $(\mathrm{PV})=0.007<0.05$ (significance level); all other three predictors have insignificant relationship with customer satisfaction as their $\mathrm{PV}=0.861>0.05,0.064>0.05$ and $0.659>0.05$ respectively.

\section{CONClusions}

From the result of the findings, the study concludes that there is a positive relationship between celebrity endorsement and customer loyalty in the Telecommunications sector in Port Harcourt. However, from the outcome of the regression analysis we conclude that not all elements of celebrity endorsement discussed in this study have significant relationship with the dependent variable. We therefore make the following specific conclusions:

1. Celebrity trustworthiness contributes significantly to customer loyalty in the Telecommunications industry in Port Harcourt. This outcome agrees with the works of Ibok (2013).

2. Credibility of an endorsed celebrity significantly influences customer loyalty in the Telecommunications industry in Port Harcourt. This conclusion is in concordance with Willemsen, Neijens and Bronner(2011).

3. Finally, we conclude based on the outcome of the study that all characteristics of an endorsed celebrity studied have significant relationship with customer commitment (i.e. perceived expertise, celebrity trustworthiness, credibility and belief are all predictors of customer commitment).

From the above conclusions, we come up with the heuristic model of the study presented figure 2 below:

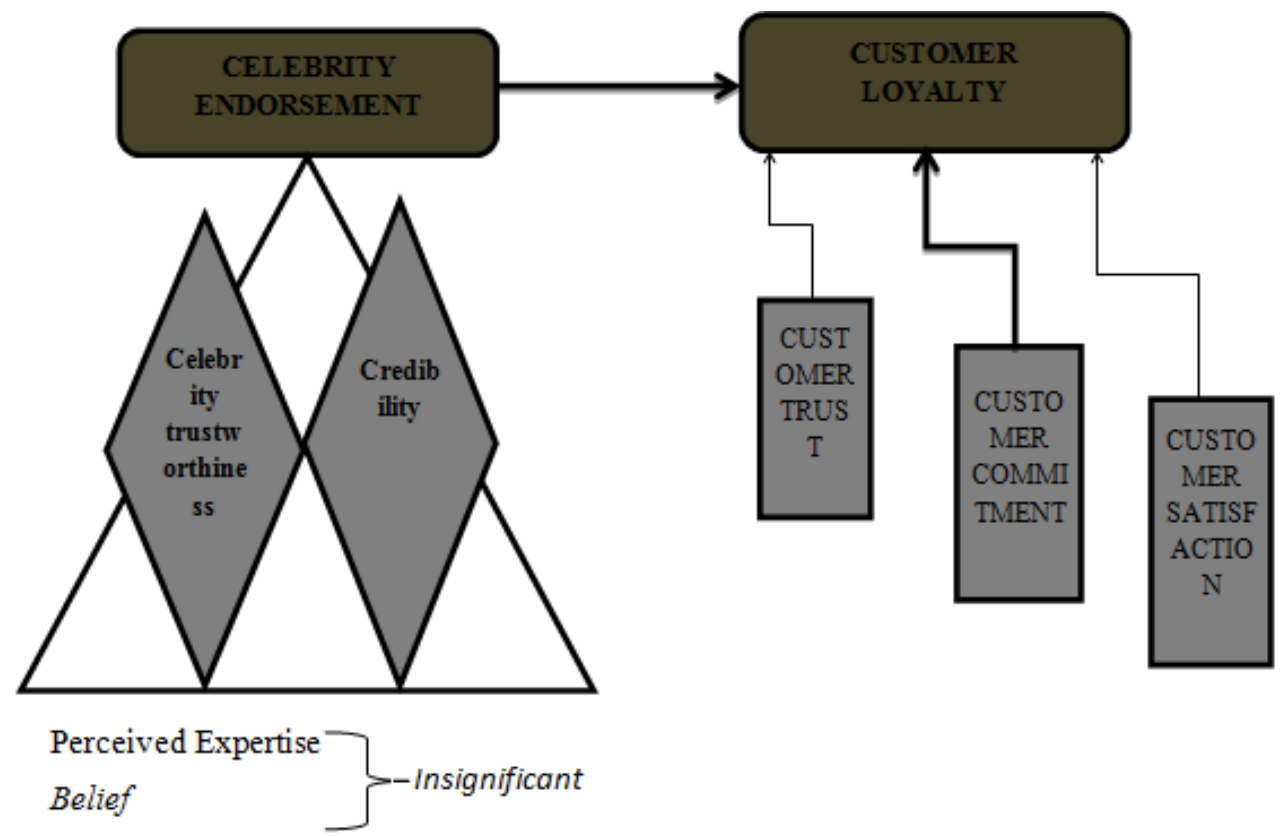

Figure2. Study's Heuristic Model

Giving the above conclusions, we accept the alternate hypotheses and state the null hypotheses where applicable as follows:

$\mathrm{HO}_{1}$ : There is no significant relationship between perceived expertise and customer trust in the Telecommunications industry in Port Harcourt.

$\mathrm{HA}_{2}$ : There is a significant positive relationship between celebrity trustworthiness and customer trust in the Telecommunications industry in Port Harcourt. 
$\mathrm{HA}_{3}$ : There is a significant relationship between credibility and customer trust in the Telecommunications industry in Port Harcourt.

$\mathrm{HO}_{4}$ : There is no significant relationship between belief and customer trust in the Telecommunications sector in Port Harcourt.

$\mathrm{HA}_{5}$ : There is a significant association between perceived expertise and customer commitment in the Telecommunications sector in Port Harcourt.

$\mathrm{HA}_{6}$ : There is a significant association between celebrity trustworthiness and customer commitment in the Telecommunications sector in Port Harcourt.

$\mathrm{HA}_{7}$ : There is a significant association between credibility and customer commitment in the Telecommunications sector in Port Harcourt.

$\mathrm{HA}_{8}$ : There is a significant association between belief and customer commitment in the Telecommunications sector in Port Harcourt.

$\mathrm{HA}_{9}$ : There is a significant relationship between perceived expertise and customer satisfaction in the Telecommunications industry in Port Harcourt.

$\mathrm{HO}_{10}$ : There is no significant positive relationship between celebrity trustworthiness and customer satisfaction in the Telecommunications industry in Port Harcourt.

$\mathrm{HO}_{11}$ : There is no significant relationship between credibility and customer satisfaction in the Telecommunications industry in Port Harcourt.

$\mathrm{HO}_{12}$ : There is no significant relationship between belief and customer satisfaction in the Telecommunications sector in Port Harcourt.

\section{STUDY IMPLICATIONS}

The implication of this study is that celebrity endorsement contributes to the overall attainment of customer loyalty in the Telecommunications industry. However, from the result of the study, not all characteristics of a celebrity endorser have equal significance on customer loyalty. This implies that some elements of the predictor variable have strong positive relationship and are also highly significant, while others show positive relationship but have no significance on the criterion variable.

Also, giving the specific objectives of the study as earlier stated prior to the conduct of the research, the study's heuristic model implies that celebrity trustworthiness and credibility contribute significantly to customer loyalty.

The implication of this study also is that although perceived expertise and belief have positive relationship with customer loyalty, the study revealed that this relationship have significance influence only on customer commitment.

\section{RECOMMENDATION}

Telecommunications companies in Port Harcourt that want to experience optimum customer loyalty should ensure that their celebrity endorsers are credible, trustworthy and free of scandals and other negative attitude capable of thwarting the trust that customers have in them and the company in general as these from the outcome of the study contribute greatly to the attainment of customer loyalty.

\section{SUgGeSTION FOR FURTHER STUDiES}

The current study was carried out on the Telecommunications sector in Port Harcourt, therefore it is suggested here that similar study be conducted in other sector of the economy and in other parts of the country.

Also, belief as an element of the predictor variable did not show much significant contribution to customer loyalty in Port Harcourt. Perhaps this is because unlike other states in Northern Nigeria, Rivers State in general and its capital city - Port Harcourt in particular is a "circular state" so to speak and not too keen about religious affiliation of the people and individual beliefs. Giving this, the 
current study suggests that an in-depth study on this element belief be carried out in other states in the Northern part of the country in order to appreciate its importance/ relevance to celebrity endorsement strategy.

\section{REFERENCES}

[1] Ahmed, R.R., et.al (2015). Impact of celebrity endorsement on consumer buying behaviour. Journal of marketing and consumer research 16. ISSN 2422-8451

[2] Apeoye, A. (2013). Influence of celebrity endorsement of advertisement on students' purchase intention. Mass communication and journalism 3(3), 1-7. http://dx.doi.org/10.4172/2165-7912.1000152

[3] Asogwa, F.O., Ohaleme, K. K. \&Ugwuanyi, R. O. (2013).The impact of telecommunication expenditure on economic growth in Nigeria. Journal of economics and sustainable development 4(13), ISSN 2222 2855 (online)

[4] Ateke, B.W. et.al. (2015). The relationship between celebrity endorsement and brand image in the fastfood industry in Port Harcourt, Nigeria. European journal of business and management 7 (27).ISSN 22222839 (online).

[5] Aydin, S. \& Ozer, G. (2004).The analysis of antecedents of customer loyalty in the Turkish mobile telecommunication market. European journal of Marketing 39(7/8), 910-925. Emerald group publishing limited 0309-0566. DOI 10.1108/03090560510601833

[6] Aydin, S., Ozer, G. \&Arasil, O. (2005). Customer loyalty and effect of switching costs as a moderating variable: a case in Turkish mobile phone market. Marketing intelligence \& planning 23(1), 89-103. Emerald group publishing ltd. 0263-4503 DOI: 10.1108/02634500510577492.

[7] Bergkvist, L. \& Zhou, K.Q. (2016). Celebrity endorsements: a literature review and research agenda. International journal of advertising 35(4), 642-663.http://dx.doi.org/10.1080/02650487.2015.1137537.

[8] Bolton, R. N., Kannan, P.K. \& Bramlett, M.D. (2000). Implication of customer loyalty program membership and customer experiences for customer retention and value. Journal of the academy of marketing science 28(1), 95-108.

[9] Bontis, N., Booker, L.D. \& Serenko, A. (2007).The mediating effect of organizational reputation on customer loyalty and service recommendation in the banking industry. Management decision 45(9), 14261445. Emerald group publishing ltd ISSN: 0025-1445. DOI 10.1108/00251740710828681.

[10] Chang, H.H.\& Chen, S.W. (2009). Consumer perception of interface quality, security, and loyalty in electronic commerce. Information \& management 46, 411-417. ISSN: 0378-7206. OElsevier. DOI: 10.1016/j.im.2009.08.002

[11] Chaudhary, U. \&Asthana, A. (2015). Impact of celebrity endorsements on consumer brand loyalty: does it really matter? International Journal of Scientific and Research Publications (5)12, 220-225. ISSN 22503153.

[12] Delgado-Ballester, E. \& Munuera- Alema An, J.L. (2001). Brand trust in the context of consumer loyalty. European journal of marketing 35(11/12), 1238-1258.

[13] Dick, A. \&Basu, K. (1994). Customer loyalty: toward an integrated conceptual framework. Journal of the academy of marketing science 22(2), 99-113

[14] Fournier, S. \& Yao, J. L. (1997). Reviving brand loyalty: a reconceptualization within the framework of consumer-brand relationships. International journal of research in marketing 14, 451-472.Elsevier science.

[15] Haghkhah, A. et.al.(2013). Commitment and customer loyalty in business-to-business context. European journal of business and management 5(19). ISSN: 222-1905 (paper).

[16] Hassan, S.R. \&Jamil, R.A. (2014). Influence of celebrity endorsement on consumer purchase intention for existing products: a comparative study. Journal of management Info 4(1), 1-23.

[17] Huang, Y. \&Huddleston, P. (2009). Retailer premium own-brands: creating customer loyalty through ownbrand products advantage. International journal of retail \&distribution management 37 (11), 975-992. Emerald Group Publishing Limited0959-0552. DOI 10.1108/09590550910999389

[18] Hsieh, A. \& Li, C. (2008).The moderating effect of brand image on public relations. Marketing intelligence and planning 26(1), 26-42. DOI 10.1108/02634500810847138.Emerald group publishing ltd.

[19] Ibok, N.I. (2013). Factors determining the effectiveness of celebrity endorsed advertisements: the case of Nigerian Telecommunication industry. American journal of business and management 2(3), 233-238 DOI: 10.11634/216796061302394. ISSN 2167-9614 (online) 
[20] Jain, V. (2011). Celebrity endorsement and its impact on sales: a research analysis carried out in India. Global journal of management and business research 11(4). ISSN: 0975-5853.

[21] Jones, T. \& Taylor, S.F. (2007). The conceptual domain of service loyalty: how many dimensions? Journal of service marketing 21(1), 36-51.Emerald group publishing ltd. ISSN 0887-6045. DOI 10.1108/08876 040710726284

[22] Kassim, N. \& Abdullah, N. A. (2010). The effect of perceived service quality dimensions on customer satisfaction, trust, and loyalty in e-commerce settings: A cross cultural analysis. Asia Pacific Journal of Marketing and Logistics, 22(3), $351-371$

[23] Keiningham, T. L., et.al. (2007). The value of different customer satisfaction and loyalty metrics in predicting customer retention, recommendation, and share-of-wallet. Managing Service Quality 17(4), 361-384. Emerald Group Publishing Limited. 0960-4529. DOI 10.1108/09604520710760526

[24] Lee, S., Barker, S. \&Kandampully, J. (2003).Technology, service quality, and customer loyalty in hotels: Australian managerial perspectives. Managing service quality 13(5), 423-432.\# MCB UP Limited. ISSN 0960-4529DOI 10.1108/09604520310495886

[25] Lee-Kelley, L., Gilbert, D. \& Mannicom, R. (2003). How e-CRM can enhance customer loyalty. Marketing intelligence and planning 21(4), 239-248. ISSN 0263-4503 DOI 10.1108/02634500310480121. MCB UP Ltd.

[26] Lervik-Olsen, L., \& Johnson, M. D. (2003). Service equity, satisfaction, and loyalty: From transactionspecific to cumulative evaluations. Journal of Service Research, 5(3), 184-195. DOI: 10.1177/10946705 02238914 Reprinted with permission. All rights reserved (C) Sage. Retrieved [20/06/2017]

[27] Malik, H.M. \&Qureshi, M.M. (2016).The impact of celebrity endorsement on consumer buying behaviour. Journal of marketing and consumer research 26, 112- 127. ISSN: 2422-8451

[28] Makumbura, U. (2015). The power of celebrity endorsements today. London school of marketing. Retrieved: [20/06/2017]

[29] Mishra, P., Dhar, U. \&Raotiwala, S. (2001). Celebrity endorsers and adolescents: a study of gender influences. Vikalpa Notes 26(4), 59-66 October- December.

[30] Ndubisi, N.O. (2007). Relationship marketing and customer loyalty. Marketing Intelligence \& Planning 25(1), 98-106. 0263-4503. DOI: 10.1108/02634500710722425. Emerald Group Publishing Limited

[31] Pamar, B.K.J. \& Patel, R.P. (2015). Fame versus no name: gauging the impact of celebrities and noncelebrities endorsement on purchase. African journal of business management 9(4), 127-133.ISSN 19938233.

[32] Poghosyan, A. (2015). Celebrity endorsement as one of nowadays major ways to influence consumer buying behaviour. European Scientific Journal, April. ISSN: 1857 - 7881 (print).

[33] Rauyruen, P., Miller, K.E. \& Barrett, N.J. (2007). Relationship quality as a predictor of B2B customer loyalty. School of marketing, University of Technology, Sydney.

[34] Ribbink, D., Reil, A.C.R., Liljander, V. \& Streukens, S. (2004). Comfort your online customer: quality, trust and loyalty on the internet. Managing service quality, 14(6), 446-456.

[35] Rundle-Thiele, S. (2005).Exploring loyal qualities: assessing survey-based loyalty measures. Journal of Services Marketing 19/7 92-500.Emerald Group Publishing Limited [ISSN: 0887-6045]. DOI:10.1108/ 08876040510625990]

[36] Serban, C. (2010). Marketing communication in online social programs: Ohanian model of source credibility. https://www.researchgate.net/publication/49615005

[37] Shah, D., Rust, R.T., Parasuraman, A., Staelin, R. \& Day, G. S. (2006).The Path to Customer Centricity. Journal of Service Research 9, 113. DOI: 10.1177/1094670506294666. Published by Sage publications. http://www.sagepublications.com

[38] Shugan, S. M. (2005). Brand Loyalty Programs: Are They Shams? Marketing science 24(2):185-193. https://doi.org/10.1287/mksc.1050.0124. ISSN: 1526-548X_05_2402_0185

[39] Soderlund, M. (2006).Measuring customer loyalty with multi-item scales: A case for caution. International Journal of Service Industry Management 17(1), 76-98 Emerald Group Publishing Limited. 0956-4233. DOI 10.1108/09564230610651598

[40] Suh, J. \& Yi, Y. (2006). When Brand Attitudes Affect the Customer Satisfaction-Loyalty Relation: The Moderating Role of Product Involvement. Journal of consumer psychology, 16(2), 145-155. Copyright Lawrence Erlbaum Associates, Inc.

[41] Toufaily, E., Ricard, L. \&Perrien, J. (2013). Customer loyalty to a commercial website: descriptive metaanalysis of the empirical literature and proposal of an integrative model. Journal of business research 66, 1436-1447. Doi: 10.1016/j.jbusres.2012.05.011 
[42] Waldt, DLR., Loggerenberg, M. \&Wehmeyer, L. (2009). Celebrity endorsements versus created spokespersons in advertisement: a survey among students. SAJEMS NS 12 (2009) No.1.

[43] Willemsen, L.M., Neijens, P.C. \&Bronner, F.E. (2011). Perceived expertise vs. perceived trustworthiness: the suppressed effect of source type on review attitude. Advances in advertising research 2, 423436. Springer.

[44] Wirtz, J., Mattila, A. S. \&Lwin, M. O. (2007). How effective are loyalty reward programs in driving share of wallet? Journal of Service Research, 9(4) May, 327-334. DOI: 10.1177/1094670506295853. CSage Publications.

[45] Worthington, S., Russell-Bennett, R. \&Hartel, C.E.J. (2009).A tri-dimensional approach for auditing brand loyalty. Journal of brand management, 17(4), 243-253

[46] Zipporah, M.M.\& Mberia, H.K. (2014). The effects of celebrity endorsement in advertisements. International journal of academic research in economics and management sciences 3(5), 178-188. ISSN: 2226-3624. DOI: 10.6007/IJAREMS/v3-i5/1250 URL: http:// dx.doi.org/ 10.6007/ IJAREMS/v3-i5/1250

\section{AUTHORS' BIOGRAPHY}

Bright ZorBari-Nwitambu, is a staff of Ken Saro-Wiwa Polytechnic, Bori -Ogoni in Rivers State, Nigeria. She works in the Library department of the Polytechnic and is currently pursuing a Doctorate degree (Ph.D.) in Marketing at the University of Port Harcourt, Port Harcourt. ZorBari-Nwitambu is a Christian, happily married and blessed with a son.

Sylva Ezema Kalu, is a professor of marketing and lectures in the University of Port Harcourt, Port Harcourt-Nigeria. He is currently the Director, Institute of International Trade and development, University of Port Harcourt. Sylva Ezema Kalu has several marketing books and journals to his credit. He is happily married and blessed with lovely children.

Citation: Bright, ZorBari-Nwitambu, and Sylva Ezema Kalu. "Celebrity Endorsement and Customer Loyalty in the Telecommunications Industry in Port Harcourt." International Journal of Managerial Studies and Research (IJMSR), vol 5, no. 9, 2017, pp. 57-71. doi: http://dx.doi.org/10.20431/2349-0349.0509010.

Copyright: ( $) 2017$ Authors. This is an open-access article distributed under the terms of the Creative Commons Attribution License, which permits unrestricted use, distribution, and reproduction in any medium, provided the original author and source are credited. 